\title{
Genetic Divergence in Sugarcane under Water-Logging Condition and Identification of Tolerant Clones
}

\author{
Rupesh Kumar Agrawal* and Balwant Kumar \\ Plant Breeding and Genetics, S.R.I., Dr.R.P.C.A.U., Pusa, Bihar, Samastipur-848 125, India \\ *Corresponding author
}

\author{
A B S T R A C T
}

\begin{tabular}{|l|}
\hline Key w or d s \\
Cluster, \\
D 2, \\
genetic \\
divergence, water- \\
logging tolerant, \\
identification, \\
sugarcane. \\
\hline Article Info \\
\hline $\begin{array}{l}\text { Accepted: } \\
\text { 29 June 2017 } \\
\text { Available Online: } \\
\text { 10 July } 2017\end{array}$ \\
\hline
\end{tabular}

\begin{abstract}
Sixteen sugarcane clones including two checks were planted with three replications in RBD at Paddy Block, RAU Pusa Farm, Samastipur, Bihar during 2012-13 under low land area where its grand growth phase coincides with water-stagnation depth $40-45 \mathrm{~cm}$ for three months to study the genetic divergence in sugarcane under Water-Logging condition and identification of tolerant Clones. Observations were recorded for the traits viz, Germination Percentage at 45 days, Number of Shoots at 120 days, Plant Height at 150, 240 and 360 days, Cane diameter, NMC, Single Cane weight, Red Rot Score, Brix at 10, 11 and 12 month, Pol at 10,11 and 12 month, Purity at 10,11 and 12 month, CCS Per cent at harvest and Cane yield. Highly significant variation was observed for all traits except purity at 10 and 11 month stage and CCS percent at harvest. All the sixteen genotypes taken for genetic divergence analysis differed significantly with regard to the characters studied and displayed marked divergence and grouped into five clusters following Tocher's method, Cluster II had eight genotypes viz. CoP 02061, BO146, CoP 04181, BO141, BO91(C), BO147(C), BO154 and CoP 09437 followed by Cluster I and having number of varieties (5) viz. CoP 11436, BO155, BO153, CoLk 94184 and CoP 09436, while Cluster III, Cluster IV and Cluster V were monogenotypic, comprising single clone CoSe 96436, CoP 08436 and CoX 07067 respectively. The maximum inter cluster distance was observed between cluster IV and V followed by cluster III and $\mathrm{V}$, cluster I and V and cluster II and IV. The highest contribution in the manifestation of genetic divergence was exhibited by cane yield (52.50) followed by CCS per cent at harvest (20.83), pol at 11 month stage (9.17), brix at 12 month stage (5.00), plant height at 360 days (5.00), number of millable canes (4.17), pol at 12 month stage (2.50). of the best performing clones viz. BO154, CoP 092, CoP 02061, CoX 07067 and BO155 were identified as water-logging tolerant genotypes coupled with high to moderate sucrose, CCS (t/ha) and acceptable morphological appearance of plant at the time of harvest. Identification of above said clones among the genetically diverse genotypes under water-logging condition will be utilized as a water-logging tolerant clone for farmers as well as it can be utilized as a parent in sugarcane crossing programme. It is suggested that genotypes with high index for specific characters that fall into different clusters could be intercrossed to generate good number of sugarcane progenies having greater potentiality for breeding purpose by virtue of their desirable characters.
\end{abstract}

\section{Introduction}

Sugarcane varieties in commercial cultivation are complex polyploids, the heterozygous and polyploid nature of this crop has resulted in generation of sufficient genetic variability. Selection of suitable clones for utilization in sugarcane improvement programme is an important but rather difficult task for plant breeders. Diversity analysis helps in assessing the nature of diversity in order to identified genetically diverse genotypes for their use in breeding programmes. In sugarcane breeding programme the diversity of parents is always emphasized. More diverse the parent within a reasonable range, better the chances of 
improving economic characters under consideration in the resulting offspring. Sugar industries in Bihar is facing several challenges and most of the sugarcane industries are closed since last three decade due to various reason, among them major is 35-40 per cent of sugarcane growing area (presently total area under sugarcane in the state is 3.00 lakh ha) in Bihar is prone to water-logging situation. Low productivity of sugarcane in Bihar has been recorded since last fifty year approximately 30-50 t/ha. Water-logging for the early stage of crop growth affects the germination, tillering and cane growth, which may result in crop failure. Generally, the water-logging coincides with the grand growth phase and may extend up to maturity of the crop and hence, the early planted crop suffers less. Higher water table during active growth phase adversely affects stalk weight and plant population resulting yield loss at the rate of about one tonne per acre for one inch increase in excess water Carter and Floyed (1974), Carter, C. E, (1976). Problem of water-logging is not only persist in Bihar rather a considerable area under sugarcane crop in several parts of India (Assam, West Bengal, and eastern Uttar Pradesh, Coastal region of Andhra Pradesh, Tamil Nadu, Kerala and Karnataka) are exposed to stagnant water for two to three months during monsoon season.

A large difference in varietal response to water-logging in sugarcane has been reported as we know that varieties differ in degree of tolerance to water-logging based on certain inherent genetic characteristics, age of the crops and other growing conditions. The varieties which are doing comparatively well under water-logging situation in Bihar are BO91 and BO147 therefore these two varieties used as checks in present investigation. The clonal differences in the response of severe water-logging was studied and found that under artificially created conditions of prolonged water-logging Saccharum spp. Hybrid Complex clones were highly susceptible and did not survive whereas the clones of Saccharum barberi, Saccharum sinense, Saccharum sclerostachya and Saccharum erianthus survived. Several clones of Saccharum spontaneum, Saccharum robustum and Saccharum narenga were water-logging tolerant. In the breeding of sugarcane, it has been a general practice to cross the different species with the noble cane, $S$. officinarum, to combine the high sugar yield of the officinarum clones with hardiness and disease resistance of the other species, a procedure called nobilization. Todays hybrid complexes i.e. Saccharum spp. clones with water-logging tolerant genes can do well under water-logging condition which requires systematic study on their comparative tolerance and knowledge of genetic divergence among the genotypes. Although the use of high yielding varieties coupled with moderate to high sucrose and also having water-logging tolerance capacity contribute substantially in sugarcane production and productivity but still there is need to screen sugarcane varieties tolerant to water-logging condition for its better adaptability and to overcome the problem of water-logging areas under sugarcane cultivation which will enhance the productivity as well as recovery of this crop. Therefore, keeping in view of the above said facts, the proposed investigation was carried out to determine the Genetic Divergence among the Sugarcane Clones.

\section{Materials and Methods}

Experimental material in the present investigation were sixteen sugarcane clones viz, BO153, BO141, CoSe96436, CoX07067, CoP081, CoP091, CoP02061, CoP111, CoP04181, BO155, BO154, BO146, CoP092 (CoP 9437), Colk94184 including two checks namely BO91 and BO147 planted at Paddy Block, RAU Pusa Farm, Samastipur, Bihar 
during 2012-2013 under low land area where stagnation of water-logging up to a minimum depth of $40-45 \mathrm{~cm}$ maintained in the three months from July to October. All the sixteen clones were planted in Randomized Block Design (RBD) with three replications follow all agronomical package and practices. In each replication each variety was grown in a plot of 6 rows of 6 meters length each with a spacing of 0.90 meter between rows and net plot size is $32.4 \mathrm{~m}^{2}$. Observation were record by selecting five random plants per genotype per replication for cane yield and yield attributing characters. Three budded sets of each genotype at the rate of 12 buds per meter were planted in 6 rows of $6 \mathrm{~m}$ length with inter-row spacing of $90 \mathrm{~cm}$.

The data from different clones were recorded for various growth and cane yield parameter viz. cane yield (t/ha), number of millable canes 12 months $(000 / \mathrm{ha})$, cane length $(\mathrm{cm})$, cane diameter $(\mathrm{cm})$, single cane weight $(\mathrm{kg})$, no. of shoots (000/ha) 240 days, no. of tillers (000/ha) and germination \% 45 days under. Cane yield ( $\mathrm{t} / \mathrm{ha}$ ) was recorded from final harvested crop, number of millable canes were counted after 12 months duration of crop per plot and converted in to MNC (000/ha). Cane length of five plants was marked from each genotype to measure cane length. The cane length was measured from base to the tip of cane at the time of harvesting when plant attained maximum growth. Same five canes were used for measurement of cane diameter with help of Vernier caliper. Single cane weight was recorded from the same set of five cane used for length and diameter. The mean data of five plants was used for statistical analysis. No. of shoots (000/ha) were recorded at the 240 days old crop and same for no. of tillers (000/ha). Germination (\%) at 45 days was calculated from the Total no. of bud/No. of Germination $\times 100$ or No. of sown buds/plot. The CCS \% and CCS (t/ha) were calculated as:
CCS $(\%)=0.292 \times$ Pol \% juice $((0.035 \times$ Purity \%)-1) / Purity \% X 100

$\operatorname{CCS}(\mathrm{t} / \mathrm{ha})=\operatorname{CCS}(\%) \times$ Cane yield $(\mathrm{t} / \mathrm{ha})$

\section{Statistical analysis}

Genetic divergence among 16 varieties of sugarcane was estimated by analyzing the data on sixteen characters through $\mathrm{D}^{2}$ statistics (Mahalanobis, 1936) in Fig. 2.. It involved the following steps:

The varieties were evaluated in replicated field trials.

Observations were recorded on various quantitative characters and variances, covariances were calculated.

Genotypic Variance $\left(\sigma_{\mathrm{g}}{ }^{2}\right)=(\mathrm{vMSS}-\mathrm{EMSS}) \mathrm{x}$ $\mathrm{CF}$

Phenotypic variance $\left(\sigma_{\mathrm{p}}^{2}\right)=\sigma_{\mathrm{g}}^{2}+$ EMS

$\mathrm{D}^{2}$ values were calculated by using the formula

$$
\mathrm{D}^{2}=\mathrm{W}_{\mathrm{ij}}\left(\bar{X}_{\mathrm{i}}{ }^{1}-\bar{X}_{\mathrm{i}}^{2}\right)\left(\bar{X}_{\mathrm{j}}{ }^{1}-\bar{X}_{\mathrm{j}}^{2}\right)
$$

Where,

$\mathrm{W}_{\mathrm{ij}}=$ Inverse of estimated variance, covariance matrix.

$\left(\bar{X}_{\mathrm{i}}^{1}-X_{\mathrm{i}}^{2}\right)$ and $\left(\bar{X}_{\mathrm{j}}{ }^{1}-\bar{X}_{\mathrm{j}}{ }^{2}\right)=$ Differences in the mean of the two populations.

Contribution of individual character towards total divergence was checked out by taking the percentage of number of times each character ranked first on the basis of

$d_{i}=Y_{i}^{j}-Y_{i}^{k}$

Where, 
$\mathrm{d}_{\mathrm{i}}=$ Mean deviation in population

$Y_{i}^{j}$ and $Y_{i}{ }^{k}=$ Values for characters in population

Rank 1 was given to the highest mean difference and ' $p$ ' to the lowest mean differances, where ' $p$ ' is the total number of characters. Using these ranks, a table was prepared to determine the percentage contribution of each character to the total divergence.

Genotypes were grouped into various clusters by on the basis of Tocher's methods Rao, (1952). It was carried out in the following steps:

The population was arranged in ascending order on the basis of their relative distances $\left(\mathrm{D}^{2}\right.$ values $)$ from each other

Two populations having small distance from each other were considered first. Then second population having smallest $\mathrm{D}^{2}$ from the first two populations was added to it.

This step was continued until the average increase in $\mathrm{D}^{2}$ value did not exceed the maximum $\mathrm{D}^{2}$ value between any two populations in the first row of the table.

The average intra cluster and inter cluster distance were calculated following the methods of Singh and Chaudhary (1977).

Average intra cluster distance was estimated by using the formula

$\sum D_{i}^{2} / n$

Where,

$\sum \mathrm{D}_{\mathrm{i}}^{2}=$ the sum of distance between all possible combinations (n) of the population included in a cluster.
Average inter cluster distance was estimated by using the formula

$\sum D_{i}^{2} /\left(n_{1} \times n_{2}\right)$

Where,

$\sum D_{i}^{2}=$ Sum of distance of all possible combinations of genotypes included in the two clusters considered

$\mathrm{n}_{1}=$ Number of genotypes in first cluster

$\mathrm{n}_{2}=$ Number of genotypes in second clusters

A cluster diagram was prepared showing the distances between clusters and genotypes on the basis of methods as explain above.

All the sixteen genotypes based on statistical differences were used for genotypes classification in different clusters, results of inter and intra clusters $\mathrm{D}^{2}$ values between clusters, as well as mean of intra-clusters $D^{2}$ values of different clusters are presented in tables $1-4$ and figures 1 and 2.

\section{Results and Discussion}

Diversity analysis helps in assessing the nature of diversity in order to identified genetically diverse genotypes for their use in breeding programmes. In sugarcane breeding programme the diversity of parents must be emphasized for bi-parental/poly crossing. More diverse the parent within a reasonable range, better the chances of improving economic characters under consideration in the resulting offspring. Mahalnobis's $D^{2}$ statistic is an unique tool for classifying genetically diverse parents based on quantitative traits (Fig.2) which could be appropriately utilized in hybridization programme. In the present investigation clustering pattern in the sixteen genotypes taken for genetic divergence analysis differed 
significantly with regard to the characters studied and displayed marked divergence and grouped into five clusters following Tocher's method (Table 1 and Fig. 1). Cluster II had eight genotypes namely. CoP02061, BO146, CoP04181, BO141, BO91(C), BO147(C), BO154 and CoP092 followed by Cluster I and having five genotypes viz. CoP11, BO155, BO153, CoLk94184 and CoP091, while Cluster III, Cluster IV and Cluster V were monogenotypic, comprising single genotype, CoSe96436, CoP081 and CoXo7067 respectively. Among the five clusters on the basis of $\mathrm{D}^{2}$ statistics, Cluster II comprises highest number of genotypes (8) followed by cluster I (5), while cluster III, Cluster IV and Cluster V were solitary comprising single genotype each. Similar studied based on $\mathrm{D}^{2}$ statistic was also performed by Ahmed and Obeid (2010), Bakshi and Hemaprabha (2005), Gagan et al., (2005), Hooda et al., (1989), Kashif and Khan (2007), Mali et al., (2009), Mishra et al., (2005), Rao et al., (1985), Silva et al., (2011), Singh and Khan (1990), Singh and Singh (2002), Singh et al.,(1987), Singh et al., (2001) and Singh et al., (2004). Cluster means for different characters under water-logging condition has been presented in table 2. A comparison of the mean values of nineteen traits for different clusters showed considerable differences among them. The highest mean values for germination percent at 45 days (36.59), number of shoots at 120 days (150.11), plant height at 150 days (202.30), plant height at 240 days (301.22), purity at 12 month stage (92.54), plant height at 360 days (327.37), cane diameter (2.84), single cane weight (0.97) and cane yield (91.28) were observed in cluster V. Cluster III have maximum mean value for brix at 10 month stage (20.20), pol at 10 month stage (17.36), brix at 11 month stage (19.40), pol at 11 month stage (16.66), brix at 12 month stage (19.77) and CCS per cent at harvest (12.02). Cluster I having maximum mean value for purity at 11 month stage
(87.66) and number of millable canes (112.61) while cluster IV having maximum mean value for purity at 10 month stage (88.95). Cluster II having no maximum value for any traits studied. The mean of intra and inter cluster distances $\left(\mathrm{D}^{2}\right)$ under water-logging condition has been presented in table 3 . The average distance of intra cluster ranged from 282.75 to 6760.25. Maximum intra cluster distance was observed in cluster II (6760.25) followed by cluster I (282.75). The highest inter cluster distance was recorded between cluster IV and V (5763.19) followed by cluster III and V (4350.43), cluster I and V (2297.42), cluster II and V (1835.66), cluster II and IV (1752.25), cluster I and IV (1497.59) and cluster II and III (1458.86), cluster III and IV (1047.88) and cluster I and III (740.67). The lowest inter cluster distance was observed between cluster I and II (678.76). The genotypes in cluster IV and cluster $\mathrm{V}$, due to maximum inter cluster distance between them, exhibited high degree of genetic diversity followed by cluster III and cluster V, cluster I and V and cluster II and cluster V, cluster II and IV, cluster I and IV, cluster II and III, cluster III and IV and cluster I and III, thus they may be utilized under inter varietal hybridization programme (transgressive breeding) for getting high yielding recombinants. The lowest inter cluster distance was observed between cluster I and II showing these clusters were relatively less divergent and crossing between them cannot produce vigorous offspring.

These results of genetic diversity study were in agreement with that of Gulzar et al., (2015), Mishra et al., (2005), Singh and Singh (2002) and Singh et al., (2001). Kashif and Khan (2007) reported that Metroglyph scatter diagram shows four groups from 14 genotypes of sugarcane. The clustering pattern showed that varieties developed from same institution were noticed to have fallen into two different clusters. 
Table.1 Clustering pattern of 16 genotypes of sugarcane for nineteen traits on the basis of D2 statistic under water-logging condition

\begin{tabular}{|l|l|l|}
\hline $\begin{array}{l}\text { Cluster } \\
\text { No. }\end{array}$ & No. of Genotypes within cluster & Genotypes in cluster \\
\hline I & 5 & CoP111, BO155, BO153,CoLk94184, CoP091 \\
\hline II & 8 & CoP02061, BO146, CoP04181, BO141, BO91, BO147, BO154, CoP092 \\
\hline III & 1 & CoSe96436 \\
\hline IV & 1 & CoP081 \\
\hline V & 1 & CoXo7067 \\
\hline
\end{tabular}

Table. 2 Cluster mean for nineteen characters in sugarcane under water-logging condition

\begin{tabular}{|c|c|c|c|c|c|c|c|c|c|c|c|c|c|c|c|c|c|c|c|}
\hline & G\% & S120 & PH150 & PH240 & $\begin{array}{l}\text { B\%1 } \\
\text { 0 }\end{array}$ & P\% 10 & $\begin{array}{l}\text { PU\% 1 } \\
\text { 0 }\end{array}$ & В\%11 & P\%11 & $\begin{array}{l}\text { PU\% } \\
11\end{array}$ & B\%12 & P\%12 & $\begin{array}{l}\text { PU\%1 } \\
2\end{array}$ & $\begin{array}{l}\text { CCS } \\
\% \\
\end{array}$ & PH360 & CD & $\begin{array}{l}\text { SC } \\
\text { W }\end{array}$ & NMC & CY \\
\hline Cluster I & 33.59 & 137.63 & 156.06 & 196.39 & 17.20 & 15.04 & 87.56 & 18.56 & 16.25 & 87.66 & 17.06 & 14.99 & 88.01 & 10.34 & 229.45 & 2.42 & 0.69 & 112.61 & 76.54 \\
\hline Cluster II & 31.40 & 110.59 & 159.95 & 188.58 & 17.30 & 15.02 & 87.40 & 17.37 & 15.12 & 87.34 & 17.63 & 14.82 & 84.17 & 9.99 & 224.34 & 2.66 & 0.82 & 100.57 & 82.46 \\
\hline Cluster III & 32.87 & 128.50 & 174.50 & 210.40 & 20.20 & 17.36 & 86.64 & 19.40 & 16.66 & 86.04 & 19.77 & 17.41 & 88.70 & 12.02 & 235.91 & 2.33 & 0.81 & 104.06 & 84.17 \\
\hline Cluster IV & 33.99 & 132.81 & 173.42 & 207.73 & 18.60 & 16.42 & 88.95 & 18.55 & 16.12 & 87.20 & 18.18 & 15.71 & 87.00 & 10.75 & 238.37 & 2.72 & 0.91 & 97.35 & 88.07 \\
\hline Cluster V & 36.59 & 150.11 & 202.30 & 301.33 & 17.30 & 14.88 & 86.02 & 18.53 & 15.10 & 81.54 & 18.03 & 16.67 & 92.54 & 11.77 & 327.37 & 2.84 & 0.97 & 94.10 & 91.28 \\
\hline
\end{tabular}

Table.3 Mean intra and inter cluster distance (D2) among five clusters in sugarcane genotypes under water-logging condition

\begin{tabular}{|l|l|l|l|l|l|}
\hline & Cluster I & Cluster II & Cluster III & Cluster IV & Cluster V \\
\hline Cluster I & 282.75 & 678.76 & 740.67 & 1497.59 & 2297.42 \\
\hline Cluster II & & 6760.25 & 1458.86 & 1752.25 & 1835.66 \\
\hline Cluster III & & & 0.00 & 1047.88 & 4350.43 \\
\hline Cluster IV & & & & 0.00 & 5763.19 \\
\hline Cluster V & & & & & 0.00 \\
\hline
\end{tabular}


Table.4 Contribution percentage of nineteen characters towards genetic divergence in sugarcane under water-logging condition

\begin{tabular}{|l|l|c|c|}
\hline $\begin{array}{l}\text { Sr. } \\
\text { No. }\end{array}$ & Characters & Times Ranked 1 & Contribution \% \\
\hline 1 & $\begin{array}{l}\text { Germination } \% \text { at 45 days after } \\
\text { planting }\end{array}$ & 0.001 & 0.00 \\
\hline 2 & Number of shoots at 120 days (000/ha) & 1 & 0.83 \\
\hline 3 & Plant height at 150 days (cm) & 0.001 & 0.00 \\
\hline 4 & Plant height at 240 days (cm) & 0.001 & 0.00 \\
\hline 5 & Brix at 10 month stage (\%) & 0.001 & 0.00 \\
\hline 6 & Pol at 10 month stage (\%) & 0.001 & 0.00 \\
\hline 7 & Purity at 10 month stage (\%) & 0.001 & 0.00 \\
\hline 8 & Brix at 11 month stage (\%) & 0.001 & 0.00 \\
\hline 9 & Pol at 11 month stage (\%) & 11 & 9.17 \\
\hline 10 & Purity at 11 month stage (\%) & 0.01 & 0.00 \\
\hline 11 & Brix at 12 month stage (\%) & 6 & 2.00 \\
\hline 12 & Pol at 12 month stage (\%) & 3 & 0.50 \\
\hline 13 & Purity at 12 month stage (\%) & 0.01 & 20.83 \\
\hline 14 & CCS per cent at harvest (\%) & 25 & 5.00 \\
\hline 15 & Plant height at 360 days (cm) & 6 & 0.00 \\
\hline 16 & Cane diameter at harvest (cm) & 0.01 & 0.00 \\
\hline 17 & Single cane weight (kg) & 5 & 4.17 \\
\hline 18 & Number of millable canes (000/ ha) & 63 & 52.50 \\
\hline 19 & Cane yield (tonne/ ha) & & \\
\hline
\end{tabular}


Table.5 Mean of CCS per cent, Cane yield, CCS (t/ha), Pol at 12th month stage and morphological characters of sixteen waterlogging tolerant Sugarcane Genotypes

\begin{tabular}{|c|c|c|c|c|c|c|c|c|}
\hline \multirow{2}{*}{$\begin{array}{l}\text { Sl. } \\
\text { No. }\end{array}$} & \multirow[t]{2}{*}{ Genotypes } & \multirow[t]{2}{*}{ Parentage } & \multirow{2}{*}{$\begin{array}{c}\text { Cane yield } \\
\text { (t/ha) }\end{array}$} & \multirow{2}{*}{$\begin{array}{c}\text { Pol \% at } 12 \\
\text { month } \\
\text { stage }\end{array}$} & \multirow{2}{*}{$\begin{array}{l}\text { CCS per } \\
\text { cent at } \\
\text { harvest }\end{array}$} & \multirow[t]{2}{*}{ CCS (t/ha) } & \multicolumn{2}{|c|}{ Morphological characters } \\
\hline & & & & & & & $\begin{array}{c}\text { Erectness } \\
\text { of stem }\end{array}$ & $\begin{array}{c}\text { Leaf colour/ Top } \\
\text { colour }\end{array}$ \\
\hline 1. & BO153 & BO131 self (BO109 X BO43) & 78.51 & 15.66 & 11.07 & 8.69 & $\mathrm{~L}$ & YELLOW \\
\hline 2. & BO141 & BO89 FC (BO47 self) & 72.56 & 14.13 & 9.49 & 6.89 & $\mathrm{~L}$ & YELLOW \\
\hline 3. & CoSe96436 & BO91 X Co62198 & 62.81 & 16.77 & 11.91 & 7.48 & NL & GREEN \\
\hline 4. & CoXo7067 & CoPant 90223 GC (BO91 GC) & 91.28 & 16.67 & 11.77 & 10.74 & NL & GREEN \\
\hline 5. & CoP081 & BO99 GC (CoP1207 X BO43) & 82.96 & 13.72 & 9.17 & 7.61 & NL & YELLOW \\
\hline 6. & CoP091 & BO91 GC & 81.05 & 16.83 & 11.85 & 9.60 & NL & YELLOW \\
\hline 7. & CoP02061 & CoLk8102 X HR 83/65 & 92.68 & 14.09 & 9.44 & 8.75 & NL & GREEN \\
\hline 8. & CoP111 & BO91 X Co62198 & 91.37 & 15.12 & 10.26 & 9.37 & NL & LIGHT GREEN \\
\hline 9. & CoP04181 & CoS8408 GC(Co1148GC) & 71.44 & 14.53 & 9.85 & 7.04 & $\mathrm{~L}$ & YELLOW \\
\hline 10 . & $\mathrm{BO} 155$ & BO122 F.C (CoP2 X BO99) & 94.45 & 15.48 & 10.37 & 9.79 & NL & GREEN \\
\hline 11. & $\mathrm{BO} 154$ & CoSe98235 X UP 9742(,„,BO91) & 97.08 & 16.82 & 11.61 & 11.27 & $\mathrm{NL}$ & DARK GREEN \\
\hline 12. & BO146 & $\mathrm{BO} 128 \mathrm{X}$ BO121 & 81.46 & 15.10 & 10.09 & 8.22 & $\mathrm{~L}$ & YELLOW \\
\hline 13. & CoP092 & BO91 GC & 96.12 & 16.84 & 11.64 & 11.19 & $\mathrm{NL}$ & DARK GREEN \\
\hline 14. & Colk94184 & CoLk8001 self & 72.22 & 17.97 & 12.39 & 8.95 & $\mathrm{~L}$ & LIGHT GREEN \\
\hline 15. & BO91 (C) & BO55 X BO 43 & 76.22 & 15.48 & 10.52 & 8.02 & NL & GREEN \\
\hline 16. & $\mathrm{BO} 147(\mathrm{C})$ & BO110 self & 82.17 & 13.31 & 9.01 & 7.40 & $\mathrm{~L}$ & DARK GREEN \\
\hline
\end{tabular}

NL- Non Lodging, L- Lodging 
Fig.1 Clustering pattern of 16 sugarcane clones on the basis of D2statistic by Tocher method

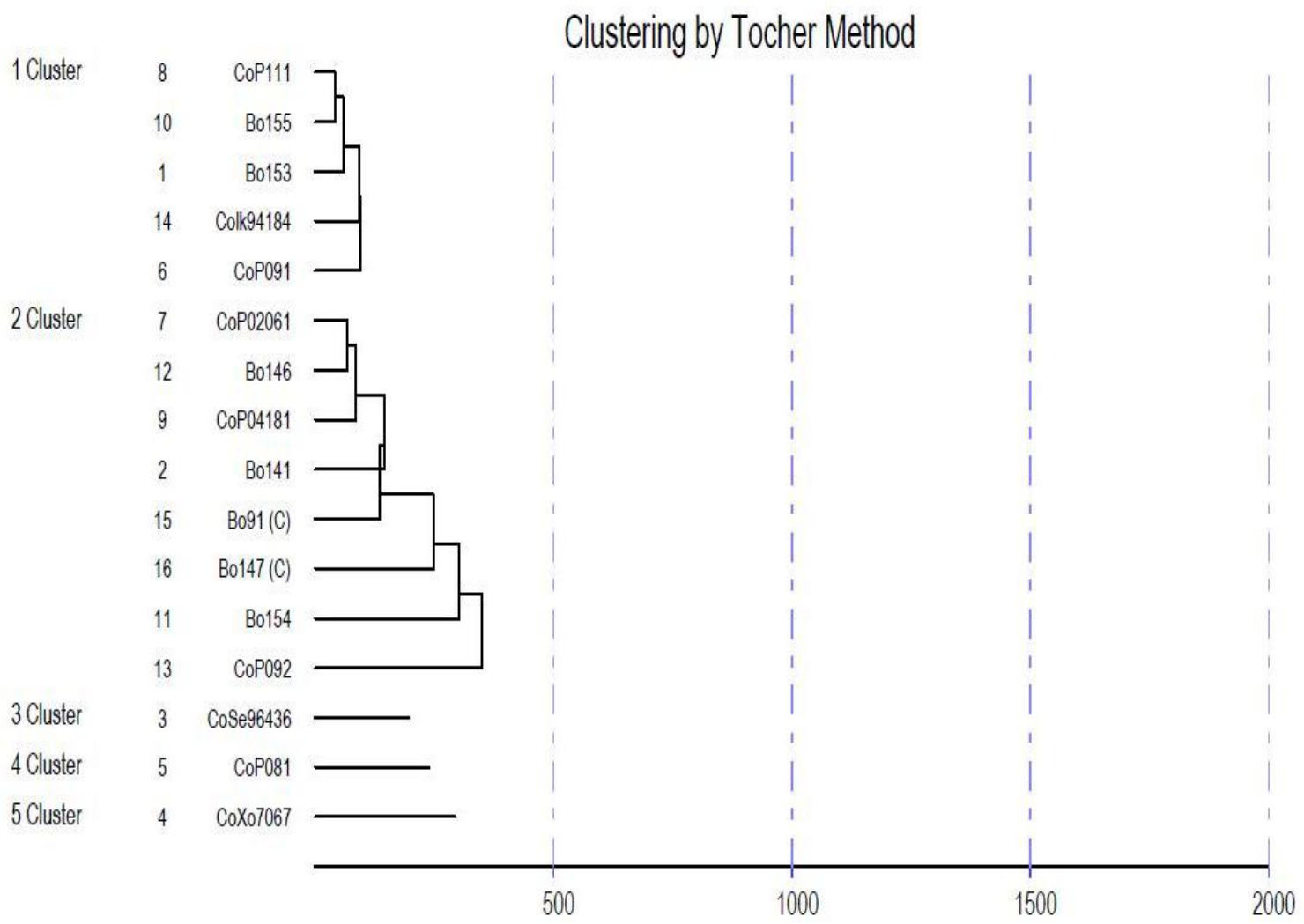

Fig.2 Mahalnobis Euclidean Disatnce among the 5 Clusters of sixteen sugarcane genotypes

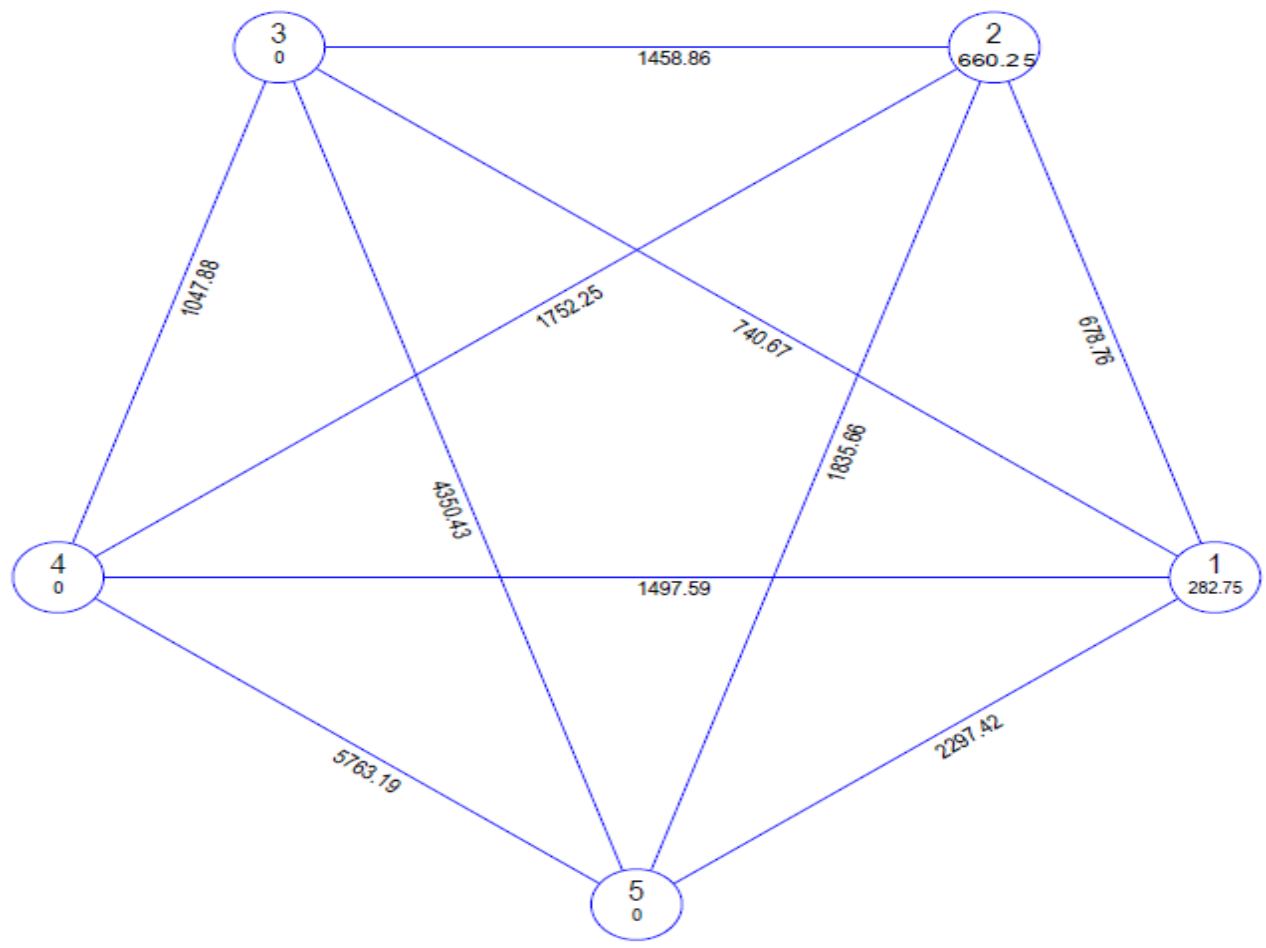


Further, it can also be seen from the cluster that the varieties in cluster III belong to different breeding stations and possible reason could be the narrow genetic base of clones used in the hybridization and limited traits explored for identification for the Bihar.

Table 4 showed contribution percentage of each character towards total divergence under water-logging condition. The highest contribution in the manifestation of genetic divergence was exhibited by cane yield (52.50) followed by CCS per cent at harvest (20.83), pol at 11 month stage (9.17), brix at 12 month stage (5.00), plant height at 360 days (5.00), number of millable canes (4.17), pol at 12 month stage (2.50). The contribution of remaining traits in manifestation of genetic divergence was negligible or zero. Different clusters comprises unique feature for different characters under investigation.

The highest mean values for germination percent at 45 days, number of shoots at 120 days, plant height at 150 days, plant height at 240 days, plant height at 360 days, cane diameter, single cane weight and cane yield were observed in cluster V. Cluster III have maximum mean value for brix $\%$ at 10 month stage, pol $\%$ at 10 month stage, brix $\%$ at 11 month stage, pol \% at 11 month stage, brix \% at 12 month stage, pol \% at 12 month stage and CCS per cent at harvest. Cluster I having maximum mean value for purity $\%$ at 11 month stage and number of millable canes while cluster IV having maximum mean value for purity at 10 month stage.

For the purpose of maximum CCS\%, cluster III, IV and cluster V were the better as at the time of harvest maximum amount of CCS (t/ha) were availed if yield were sufficient. Selection of genotypes based on cluster mean for the better exploitation of genetic potential also reported by Ahmed and Obeid (2010), Mali et al., (2009), Mishra et al., (2005),
Singh and Khan (1990) and Singh et al., (2004). The highest intra cluster distance was observed in cluster II indicating differences in genotypes within cluster. Least intra cluster distance was found in cluster I indicating that close resemblance between the genotypes presented in this cluster. Table 5 contains mean of the trais viz, CCS per cent, Cane yield, CCS (t/ha), Pol at $12^{\text {th }}$ month stage and morphological characters of sixteen waterlogging tolerant Sugarcane Genotypes for identification of high yielding, coupled with high to moderate sucrose containing sugarcane genotypes tolerant to water-logging condition. The morphological observation of sixteen genotypes under three month water-logging showed the appearance of leaf colour dark green for genotypes namely, BO154, CoP092 and BO147, Green for CoSe96436, CoX07067, CoP02061, BO155 and BO91. The Light green for genotypes viz, CoP111 and CoLk94184. Yellow colour for the genotypes namely, BO153, BO141, CoP081, CoP091, CoP04181 and BO146. The genotypes namely, CoSe96436, CoX07067, CoP081, CoP091, CoP02061, CoP111, BO155, BO154 and BO91 showed nonlodging while rest of the genotypes showed lodging. High CCS (t/ha) was observed for the genotype BO154 (11.27) followed by CoP092 (11.19), CoX07067 (10.74), BO155 (9.79), CoP091 (9.60), CoP111 (9.37), CoLk94184 (8.95), CoP02061 (8.75), BO153 (8.69), BO146 (8.22) and BO91 (8.02). The appearance of leaf colour under water logging acceptable as dark green to green colour and non lodging stem along with high yield and juice quality traits viz, CCS per cent, Cane yield, CCS (t/ha), Pol at $12^{\text {th }}$ month stage showed by the genotypes namely BO154, CoP092, CoP02061, CoX07067 and BO155

On the basis of per se performance for the traits viz, CCS per cent at harvest, CCS (t/ha), pol at 12 month stage, cane yield and acceptable morphological appearance of plant 
under water-logging condition five clones namely, BO154, CoP 092, CoP02061,, CoX 07067 and BO155 were identified. As these clones having high yielding ability coupled with high to moderate sucrose under waterlogging condition. Parentage detail for most of the identified clones indicated that water logging tolerant ability transmitted through BO 91 as a parent either GC or bi-parental cross (Table 5). The selection and choice of parents mainly depends upon contribution of characters towards divergence. Under low land area its grand growth phase coincides with water-stagnation depth up to $40-45 \mathrm{~cm}$ for three months while mean performance of five genotypes viz. BO154, CoP092, CoP02061, CoX07067 and BO155 were found superior for most of the traits. Therefore in one hand these water-logging tolerant genotypes will be useful for sugarcane farmers to get high yield and other hand sugar mills to get more sugar recovery. These clones further utilize as a water-logging tolerant parent during crossing programme.

\section{References}

Ahmed, A.O. and Obeid, A. 2010. Genetic divergence among sugarcane genotypes (Saccharum spp.) for cane yield attributes and quality determinants. African J. Agri. Res., 5(16): 2103-2107.

Bakshi, Ram and Hemaprabha, G. 2005. Genetic divergence of sugar yield and its components in flowering type Saccharum officinarum clones. Agric. Sci. Dig., 25(2): 118-120.

Carter, C.E. 1976. Excess water decreases cane and sugar yields. Proc. Am. Soc. Cane Technol., 6: 44-51.

Carter, C.E. and Floyed, J.M. 1974. Inhibition of sugarcane yields by high water level during dormant season. Proc. Soc. Sug. Cane Technol., 4: 14-18.

Creste, S., Pinto, L.R., Xavie, M.A., Landell, M.G.A. 2010. Sugarcane Breeding
Method and Genetic Mapping, In: Sugar Cane Bioethanol: R\&D for productivity and sustainability, L.A.B. Cortez (Ed.) pp: 353-357.

Gagan, Deep, Mehla, A.S., Punia, M.S. and Kadian, S.P. 2005. Studies on genetic divergence in sugarcane. Indian Sugar, 55(9): 79-84.

Gulzar Sanghera, S., Kumar, R., Tyagi, V., Thind, K.S. and Sharma, B. 2015. Genetic divergence among elite sugarcane clone (Saccharum officinarum L.) based on cane yield and quality traits from northern India. $J$. Experimental Biol. Agri. Sci., Volume 3(2).

Hooda, M.S., Singh, S. and Chaudhary, B.S. 1989. Genetic divergence studies in sugarcane. Haryana Agric. J. Res., 19(3): 249-252.

Kang, S.A., Noor, M., Khan, F.A., Saeed, F. 2013. Divergence analysis and association of some economical characters of sugarcane (Saccharum officinarum L.. J. Plant Breeding and Genetics, 1: 01-06

Kashif, M. and Khan, F.A. 2007. Divergence in sugarcane (Saccharum officinarum L.) based on yield and quality traits. Pak. J. Bot., 39: 1559-1563.

Mahalanobis, P.C. 1928. A statistical study at Chinese head measurement. J. Asiatic Society of Bengal, 25: 301-377.

Mahalanobis, P.C. 1936. On the generalised distance in statistics. Proceedings of National Institute of Science, India, 2: 49-55.

Mishra, P.K., Ashok Mishra. and Prasannajit Mishra. 2005. Genetic divergence in sugarcane. Indian Sugar, 55(5): 33-38.

Prasanna, K., Ashok, M. and Parasannajeit, M. 2005. Genetic divergence in sugarcane. Indian Sugar J., 53: 33-38.

Punia, M.S., Chaudhary, B.S. and Hooda, R.S. 1983. Genetic divergence in sugarcane. J. Agri. Sci., 53: 434-436. 
Rao, C.R. 1952. Advanced biometrical methods in biometric research. John Wiley and Sons Inc, New York. pp 357363.

Sajjad, M. and Khan, F.A. 2009. Genetic diversity among sugarcane cultivars in Pakistan. American-Eurasian J. Agri. Environ. Sci., 6: 730-736.

Singh, H.N., Rai, J.N. and Vishwakarma, R.S. 1987. Genetic divergence in sugarcane (Saccharum hybrid species. Indian Sugar Crops J., 13(2-3): 1-4

Singh, P. and Singh, V.P. 2002. Genetic divergence in sugarcane germplasm. Indian J. Agri. Sci., 72: 252-253.

Singh, P.K., Sanjeev Kumar. and Singh, J. 2004. Genetic divergence in Saccharum spp. germplasm under sub-tropics. Indian Sugar, 53(11): 903-906

Singh, P.K., Singh, J., Sanjeev Kumar. and Pandey, D.K. 2004. Genetic divergence in commercial hybrids of sugarcane
(Saccharum spp. hybrids. Cooperative Sugar, 35(11): 861-863

Singh, R.B., Bains, S.S. 1986. Genetic divergence for ginning out tern and its component in upland cotton (Gossypium hirsutum L) varieties obtained from different geographical locations. Indian J. Genetics and Plant Breeding, 26: 262-268.

Singh, S. and Khan, A.Q. 1990. Genotypic diversity in sugarcane. Crop Improvement, 17(1): 13-16

Singh, S.B., Pratap Singh, Sharma, M.L., Singh, R.K. and Singh, R.S. 2001. Studies on pattern of genetic divergence.

Snedecor, G.W., Cochran. 1967. Statistical Methods. Oxford and IBH publication Co., New Delhi.

Vivekananda, P., Subramanian, S. 1993. McGraw Hill Book, Genetic divergence in rainfed rice. Oryza, 30: 60-62.

\section{How to cite this article:}

Rupesh Kumar Agrawal and Balwant Kumar. 2017. Genetic Divergence in Sugarcane under Water-Logging Condition and Identification of Tolerant Clones. Int.J.Curr.Microbiol.App.Sci. 6(7): 4044-4055. doi: https://doi.org/10.20546/ijcmas.2017.607.419 